\title{
PENGARUH TGT BERBANTUAN MEDIA MONOPOLI ELEKTRONIK TERHADAP HASIL BELAJAR DARING KELAS IV SDN 1 PATOKPICIS MALANG
}

\author{
${ }^{1}$ Yuninda Dewi Agustin, ${ }^{2}$ Nury Yuniasih, ${ }^{3}$ Dyah Tri Wahyuningtyas \\ ${ }^{123}$ Universitas PGRI Kanjuruhan Malang \\ yunindadewiagustin@gmail.com
}

\begin{abstract}
Abstrak
Pelaksanaan pembelajaran daring guru sangat dominan dalam melakukan pembelajaran, media yang digunakan kurang menarik, sehingga siswa kurang bersemangat dalam kegiatan pembelajaran dan berdampak pada penurunan hasil belajar. Penelitian ini bertujuan untuk mengetahui pengaruh model TGT berbantuan media Monopoli Elektronik (ME 3IN1) terhadap hasil belajar siswa kelas IV. Pendekatan yang digunakan adalah penelitian kuantitatif, dengan jenis penelitian kuasi eksperimen. Sampel penelitian IVA dan IVB berjumlah 50 siswa. Instrumen penelitian menggunakan tes dalam bentuk pre-test dan post-test. Variabel bebas dalam penelitian ini yaitu model TGT dan media monopoli elektronik sedangkan variabel terikat yaitu hasil belajar siswa. Subjek penelitian yaitu siswa IV SDN 1 Patokpicis Malang. Berdasarkan hasil pengujian hipotesis diperoleh nilai signifikansi $0,00<0,05$ sehingga $\mathrm{Ho}$ ditolak $\mathrm{H}_{1}$ diterima sehingga dapat disimpulkan ada pengaruh TGT berbantuan monopoli elektronik terhadap hasil belajar. Selain itu, peningkatan hasil belajar pada kelas eksperimen yaitu sebesar 13 dari nilai rata-rata pre-test 67 dan post-test 80.
\end{abstract}

Kata Kunci: pembelajaran daring, monopoli elektronik (ME 3IN1), hasil belajar, tematik

\begin{abstract}
The implementation of online learning teachers is very dominant in carrying out learning, the media used is less attractive, so that students are less enthusiastic in learning activities and have an impact on decreasing learning outcomes. This study aims to determine the effect of the TGT model assisted by Electronic Monopoly media (ME 3IN1) on the learning outcomes of fourth grade students. The approach used is quantitative research, with the type of quasi-experimental research. The research sample IVA and IVB amounted to 50 students. The research instrument used tests in the form of pre-test and post-test. The independent variable in this study is the TGT model and electronic monopoly media while the dependent variable is student learning outcomes. The research subjects were students IV SDN 1 Patokpicis Malang. Based on the results of hypothesis testing, a significance value of $0.00<0.05$ is obtained so that Ho is rejected, HI is accepted, so it can be concluded that there is an effect of TGT assisted by electronic monopoly on learning outcomes. In addition, the increase in learning outcomes in the experimental class was 13 from the average value of pre-test 67 and post-test 80.
\end{abstract}

Keywords: online learning, electronic monopoly (ME 3IN1), learning outcomes, thematic 


\section{PENDAHULUAN}

Pembelajaran pada kurikulum 2013 menggunakan pembelajaran tematik. Pembelajaran tematik bersifat menggabungkan beberapa muatan pelajaran kedalam suatu tema, sehingga dalam satu pembelajaran siswa dapat memahami beberapa muatan pelajaran. Menurut Undang-Undang Nomor 20 Tahun 2003 dalam penelitian (Syaodih S Nana., 2009) tentang Sistem Pendidikan Nasional Pasal 1 butir 19, kurikulum adalah seperangkat rencana dan pengaturan mengenai tujuan, isi, dan bahan pelajaran serta cara yang digunakan sebagai pedoman penyelenggaraan kegiatan pembelajaran untuk mencapai tujuan pendidikan tertentu. Kurikulum biasanya dibedakan antara kurikulum sebagai rencana dengan kurikulum yang fungsional. Pembelajaran tematik menawarkan model-model pembelajaran yang sangat inovatif dan beragam dengan memberdayakan pengetahuan dan pengalaman siswa untuk membantu siswa memahami pelajaran yang disampaikan guru. Terdapat banyak sekali model pembelajaran yang dapat digunakan guru untuk mencapai tujuan pembelajaran, salah satunya yaitu model Teams Game Tournament (TGT). Tetapi pada saat ini Indonesia sedang menghadapi pandemi covid-19 sehingga dunia pendidikan juga terkena imbasnya, sekolahsekolah melakukan pembelajaran daring (dalam jaringan) atau Online. Pembelajaran.online mengacu pada "pembelajaran yang dialami melalui internet" baik dalam lingkungan sinkron atau asinkron di mana siswa terlibat dengan instruktur dan siswa lain pada waktu dan tempat yang nyaman (Dong et al., 2020). Menurut (Pangondian, et al (2019, n.d.) yang menyatakan bahwa di antara faktor-faktor yang menjadi kunci kesuksesan pembelajaran daring adalah ketersediaan sarana dan prasarana. Pembelajaran daring merupakan pemanfaatan jaringan internet dalam proses pembelajaran (Dewi, 2020). Pembelajaran daring memanfaatkan beberapa aplikasi yaitu WhatsApps, Zoom, Classroom dan Google Meet. Beberapa media daring tersebut dimanfaatkan agar kegiatan pembelajaran tetap berjalan serta interaksi antara guru dan siswa tetap terjalin. Menurut (Hussein et al., 2020) pembelajaran daring memiliki beberapa kelemahan, diantaranya yaitu keterbatasan internet, gagap teknologi, handphone atau laptop, serta pemahaman siswa tentang materi yang disampaikan guru. Beberapa kelemahan tersebut mengakibatkan kurang efisiennya pembelajaran dan mengakibatkan hasil belajar siswa menurun jika dibanding pembelajaran tatap muka sebelum adanya pandemi covid-19. 
Berdasarkan observasi yang dilakukan oleh peneliti, hasil rata-rata nilai Penilaian Akhir Semester (PAS) tahun ajaran 2019-2020 semester ganjil sebelum adanya pandemi covid-19 adalah 82.5, sedangkan nilai rata-rata nilai Penilaian Akhir Semester (PAS) siswa kelas IV tahun Ajaran 2020-2021 semester ganjil adalah 62,7. Sehingga dapat disimpulkan nilai ratarata siswa kelas IV menurun $20 \%$ saat pembelajaran daring pada masa pandemi covid 19. Oleh sebab itu, siswa sangat membutuhkan motivasi dan media pembelajaran yang sangat menyenangkan dan inovatif untuk meningkatkan hasil belajar siswa agar dapat maksimal.

Salah satu cara yang dapat digunakan untuk mengimbangi keadaan pada masa pandemi covid-19 adalah dengan memberikan model pembelajaran Teams Game Tournament (TGT) dan berbantuan media yang di dalamnya terdapat permainan. Media tersebut salah satunya adalah media Monopoli Elektronik (ME 3IN1). Permainan monopoli adalah salah satu permainan papan yang cukup terkenal. Tujuan permainan ini adalah untuk menguasai semua petak di atas papan melalui proses menyewa, menjual dan membeli dengan prinsip ekonomi yang dibuat lebih sederhana (A.Husna M, 2016). Media Monopoli Elektronik (ME 3IN1) ini memiliki 3 fungsi yaitu, sebagai media pembelajaran, sebagai permainan, serta sebagai edukasi oleh karena itu media ini disebut ME 3IN1 (Triyana et al., 2019). Dalam Monopoli Elektronik ini mempunyai peraturan yang hampir sama dengan pernainan monopoli biasanya. Dalam Monopoli Elektronik (ME 3IN1) dalam petak-petak nya terdapat materi dan soal-soal untuk 1 pembelajaran, selain itu petak-petaknya tidak berupa nama-nama negara akan tetapi di ganti dengan nama-nama pekerjaan disekitar sesuai dengan tema yang sudah di ambil untuk pembelajaran yaitu kelas 4 tema 4 Berbagai Pekerjaan.

Berdasarkan penelitian (Suciati et al., 2015) telah menghasilkan data bahwa media pembelajaran Monosa sangat efektif dan sangat menarik, dengan menggunakan media pembelajaran tersebut diharapkan peserta didik tidak merasa jenuh atau bosan karena pembelajaran dilakukan dengan bermain. Sedangkan dalam penelitian (Anis Nurhayati S., 2013) yang meneliti tentang media permainan monopoli untuk meningkatkan minat belajar siswa dengan memodifikasi permainan monopoli menjadi papan makanan dari daerah-daerah yang ada di Indonesia. Dalam penelitian ini menjelaskan bahwa permainan monopoli dapat meningkatkan motivasi belajar siswa dan membuat siswa lebih aktif dan kreatif dalam proses pembelajaran 
http://jurnal.umt.ac.id/index.php/IJOEE

Berdasarkan paparan di atas, tujuan penelitian ini adalah untuk mengetahui pengaruh model Teams Game Tournament (TGT) berbantuan media Monopoli Elektronik (ME 3IN1) terhadap hasil belajar daring siswa kelas IV di SDN 1 Patokpicis Wajak kabupaten Malang.

\section{METODE PENELITIAN}

Jenis penelitian yang digunakan dalam penelitian ini adalah eksperimen kuasai dengan pola nonequivalent control group design (pre-test dan post-test yang tidak equivalen). Dalam rancangan penelitian ini terdapat dua kelompok yaitu kelompok eksperimen dan kontrol. Pada kedua kelompok sama-sama diberi pre-test dan post-test, tetapi dalam kelompok eksperimen diberikan perlakuan menggunakan model Teams Game Tournament (TGT) berbantuan media Monopoli Elektronik (ME 3IN1), dan kelompok kontrol tidak diberikan perlakuan (konvensional). Kelas eksperimen pada penelitian ini adalah kelas IV A dan kelas IV B adalah kelas kontrol. Skema model penelitian ini adalah sebagai berikut.

Tabel 1. Rancangan Penelitian

\begin{tabular}{cccc}
\hline Kelompok & Pre-Test & Perlakuan & Post-Test \\
\hline IV A & O1 & X1 & O2 \\
IV B & O3 & X2 & O4 \\
\hline
\end{tabular}

Keterangan :

IVA : Kelompok Eksperimen

IVB : Kelompok Kontrol

O1 : Pre-Test Kelas IVA

O2: Post-Test Kelas IVA

O3 : Pre-Test Kelas IVB
O4 : Post-Test Kelas IVB

X1 : Model Pembelajaran Konvensional

X2 : Model Pembelajaran TGT

berbantuan media Monopoli Elektronik

(ME 3IN1)

Populasi dalam penelitian ini adalah seluruh siswa kelas IVA dan Kelas IVB yang berjumlah 54 siswa di SDN Patokpicis 1 Wajak, Kab. Malang.

Instrumen penelitian merupakan suatu alat yang di gunakan mengukur fenomena alam maupun sosial yang diamati (Sugiyono, 2016). Dalam penelitian ini, instrumen yang digunakan adalah insturmen pembelajaran dan instrumen pengukuran. Penelitian ini mengukur hasil belajar siswa yaitu indikator kognitif dengan menggunakan soal obyektif atau pilihan ganda. Instrumen pengukuran hasil belajar menggunakan bentuk tes obyektif sebanyak 10 soal yang disusun sebagai tujuan pembelajaran tematik dalam RPP dan 
diimplementasikan pada bagian instrumen penilaian dengan memuat beberapa aspek yaitu aspek kognitif, afektif dan psikomotor. Soal tes diberikan kepada semua sampel sesuai dengan konsep yang diberikan selama perlakuan berlangsung. Lembar tes digunakan untuk mengetahui hasil belajar siswa dalam penelitian ini. Lembar tes ini diberikan kepada sampel dan waktu pelaksanaan pengambilan data (penelitian). Tes hasil belajar yang digunakan sudah diuji validitas, reliabilitas, dan taraf kesukaran. Setelah penelitian dilakukan, peneliti melakukan analisis data menggunakan uji normalitas, homogenitas, dan uji hipotesis hingga dapat ditarik kesimpulan dari hasil penelitian ini.

\section{HASIL DAN PEMBAHASAN}

Uji statistik berbantuan SPSS 22.0 for windows yang digunakan adalah uji ShapiroWilk. Data dari hasil uji normalitas pre-test dikelas kontrol dan eksperimen tersebut menunjukkan bahwa data tersebut berdistribusi normal. Hal ini dapat dilihat dari hasil uji Shapiro wilk 0,057 > 0,05 pada kelas kontrol dan 0,045<0,05 pada kelas eksperimen sehingga $\mathrm{H} 1$ diterima yaitu data berdistribusi tidak normal. Sedangkan data dari hasil uji normalitas post-test dikelas kontrol dan eksperimen tersebut menunjukkan bahwa data tersebut berdistribusi tidak normal. Hal ini dapat dilihat dari hasil uji Shapiro wilk 0,022 < 0,05 pada kelas kontrol dan 0,022 < 0,05 pada kelas eksperimen sehingga $\mathrm{H} 0$ diterima yaitu data berdistribusi tidak normal. Berdasarkan output menghasilkan data yang tidak normal, maka dilakukan uji wilcoxon non parametrik untuk mengetahui ada tidaknya perbedaan ratarata dua sampel yang saling berpasangan. Berdasarkan output uji wilcoxon non parametrik “Test Statistics", diketahui Asymp. Sig. (2-tailed) bernilai 0,000. Karena nilai 0,000<0,05, maka dapat disimpulkan bahwa ada perbedaan antara hasil belajar siswa untuk pre-test dan post-test.

Selanjutnya pada uji homogenitas, diketahui nilai Signifikansi (Sig.) adalah sebesar $0,552>0,05$, sehingga dapat disimpulkan varians data post-test kelas eksperimen dan posttest kelas kontrol adalah sama atau homogen. Oleh karena output menghasilkan data yang tidak normal, maka setelah dilakukan uji homogenitas maka dilakukan uji Mann Whitney untuk mengetahui ada tidaknya perbedaan rata-rata dua sampel yang tidak berpasangan. Berdasarkan output uji Mann Whitney "Test Statistics” diketahui bahwa nilai Asymp. Sig. (2- 
tailed) sebesar $0,000<0,05$. Maka dapat disimpulkan bawa ada perbedaan hasil belajar siswa kelas eksperimen dan kontrol.

Selanjutnya hasil uji hipotesis atau penarikan kesimpulan. Uji hipotesis melakukan uji T dan uji F. Hasil uji T sebagai berikut :

Coefficients $^{\mathrm{a}}$

Tabel 2. Uji T

\begin{tabular}{|c|c|c|c|c|c|c|c|}
\hline & & & Unstan & Coefficients & $\begin{array}{l}\text { Standardized } \\
\text { Coefficients }\end{array}$ & & \\
\hline & / Media & & $\mathrm{B}$ & Std. Error & Beta & $\mathrm{t}$ & Sig. \\
\hline 1 & $\begin{array}{l}\text { (Constant) } \\
\text { Monopoli } \\
\text { ME 3IN1 }\end{array}$ & Elektronik & $\begin{array}{l}4,491 \\
, 526\end{array}$ & $\begin{array}{l}, 864 \\
, 128\end{array}$ & ,636 & $\begin{array}{l}5,197 \\
4,124\end{array}$ & $\begin{array}{l}, 000 \\
, 000\end{array}$ \\
\hline
\end{tabular}

a. Dependent Variable: Hasil belajar

Sumber: Hasil analisis menggunakan SPSS 22.0

Hasil uji T diperoleh nilai Sig. 0,000 < 0,05 dan nilai t hitung 4,124 > t tabel 2,060. Sedangkan hasil uji F adalah sebagai berikut :

Tabel 3. Uji F

ANOVA

\begin{tabular}{|ll|r|r|r|r|r|}
\hline Model & & Sum of Squares & df & Mean Square & F & Sig. \\
\hline 1 & Regression & 10,526 & 1 & 10,526 & 17,007 &, $000^{\mathrm{b}}$ \\
& Residual & 15,474 & 25 &, 619 & & \\
& Total & 26,000 & 26 & & & \\
\hline
\end{tabular}

a. Dependent Variable: Hasil belajar

b. Predictors: (Constant), Model Monopoli Elektronik (ME 3IN1)

Hasil uji F diperoleh nilai Sig. 0,000 < 0,05 dan nilai F hitung 17,007 > F tabel 4,23.

Disimpulkan bahwa maka $\mathrm{H}_{0}$ di terima yang berarti ada pengaruh model Teams Games Tournament berbantuan media Monopoli Elektronik (ME 3IN1) terhadap hasil belajar siswa kelas IV pada pembelajaran daring di SD Negeri 1 Patokpicis Wajak Kabupaten Malang.

Peningkatan hasil belajar siswa dilihat dari perolehan nilai yang telah diujikan. Peneliti melakukan pengujian pada kelas kontrol dan eksperimen. Tes yang dilakukan yaitu pre-test dan post-test. Rata-rata nilai siswa kelas kontrol dan eksperimen disajikan dalam grafik berikut: 


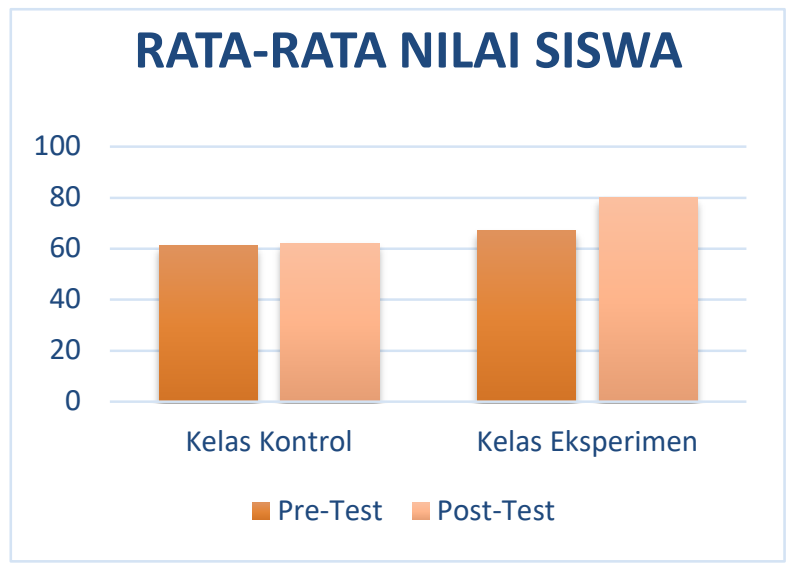

Gambar 1. Rata-rata Nilai Siswa

Tes awal yang diberikan sebelum mendapat perlakuan mendapatkan hasil yang diasumsikan sama yaitu pada kelas pre-test dengan rata-rata 61 dan pada kelas eksperimen dengan rata-rata 67. Sedangkan nilai rata-rata post-test kelas kontrol yaitu 62 dan kelas eksperimen yaitu 80. Dengan demikian ada peningkatan hasil belajar yang signifikan pada pembelajaran menggunakan media Monopoli Elektronik (ME 3IN1) sebesar 13.

Berdasarkan hasil temuan yang telah di lakukan bahwa permainan monopoli dapat memberikan pengaruh yang postif pada kegiatan pembelajaran monopoli adalah salah satu permainan papan yang paling terkenal di dunia. Tujuan permainan ini adalah untuk menguasai semua petak di atas papan melalui pembelian, penyewaan dan pertukaran properti dalam sistem ekonomi yang disederhanakan. Setiap pemain melemparkan dadu secara bergiliran untuk memindahkan bidaknya, dan apabila ia mendarat di petak yang belum dimiliki oleh pemain lain, ia dapat membeli petak itu sesuai harga yang tertera. Menurut Anis Nurhayati S., (2013) menambahkan bahwa monopoli adalah satu permainan papan dan pemain berlomba untuk mengumpulkan kekayaan melalui satu pelaksanaan sistem permainan dengan memasukkan pertanyaan yang akan dijawab oleh peserta pemain. Monopoli juga merupakan suatu permainan papan dimana pemain berlomba untuk mengumpulkan kekayaan melalui aturan pelaksanaan permainan. Pada game monopoli ada beberapa langkah yang secara otomatis dijalankan apabila memasuki kondisi tertentu, seperti saat mengambil kartu kesempatan, maka langkah atau petunjuk yang tertera pada kartu kesempatan akan secara otomatis dijalankan. Menurut (Rahaju \& Hartono, 2017) permainan monopoli dapat 
meningkatkan hasil belajar siswa apabila diinovasikan sebagai media pembelajaran. Sejalan dengan penelitian (Ulfaeni, 2018) berjudul Pengembangan Media Monergi (Monopoli Energi) Untuk Menumbuhkan Kemampuan Pemahaman Konsep Ipa dengan hasil peneitian bahwa siswa sangat antusias dalam belajar dan sangat bermotivasi dalam belajar, sehingga pemahaman siswa tentang IPA meningkat, dan hasil belajar IPA pada siswa meningkat. Maka dapat disimpulkan bahwa ada pengaruh model teams games tournament berbantuan media monopoli elektronik (ME 3IN1) terhadap hasil belajar siswa pada pembelajaran daring kelas IV di SD Negeri 1 Patokpicis Wajak Kabupaten Malang.

\section{SIMPULAN DAN SARAN}

Penelitian ini mendapat hasil adanya pengaruh model Teams Games Tournament berbantuan media Monopoli Elektronik (ME 3IN1) terhadap hasil belajar siswa pada pembelajaran daring di SD Negeri 1 Patokpicis Wajak Kabupaten Malang. Dengan perolehan pengujian normalitas mendapatkan hasil yang tidak normal, serta di dukung dengan uji Wilcoxon dan mendapatkan hasil ada perbedaan antara hasil belajar pre-test dan post-test. Uji homogenitas mendapatkan nilai signifikasi post-test di kelas kontrol dan eksperimen yaitu sebesar 0,552. Nilai tersebut menunjukkan bahwa post-test memiliki variansi yang sama atau homogen. Uji hipotesis dilakukan melalui uji $\mathrm{T}$ dan uji F. Uij $\mathrm{T}$ diperoleh nilai signifikasi (Sig.) sebesar 0,000 < 0,05 sehingga dapat disimpulkan h0 diterima dan h1 ditolak, sehingga ada pengaruh model Teams Games Tournament berbantuan media Monopoli Elektronik (ME 3IN1) terhadap hasil belajar siswa pada pembelajaran daring. uji F diperoleh nilai signifikansi (Sig.) $0,000<0,05$ dan nilai $\mathrm{F}$ hitung 17,007 > F tabel 4,23, sehingga dapat disimpulkan h0 diterima dan $\mathrm{H}_{1}$ ditolak sehingga ada ada pengaruh model Teams Games Tournament berbantuan media Monopoli Elektronik (ME 3IN1) terhadap hasil belajar siswa pada pembelajaran daring. Saran untuk peneliti selanjutnya yaitu sebaiknya melakukan penelitian lanjutan dengan mengembangkan variabel terikat yang lebih banyak, selain itu lebih mengembangkan model pembelajaran untuk diterapkan dalam pembelajaran di sekolah. 


\section{DAFTAR PUSTAKA}

A.Husna M. (2016). Permainan Tradisional Indonesia: Untuk kreativitas, ketangkasan dan keakraban. Andi Publisher.

Anis Nurhayati S. (2013). Permainan Monopoli Sebagai Media Untuk Meningkatkanminat Belajar Tata Boga Di Sma. Jurnal Ilmiah Guru Caraka Olah Pikir Edukatif, O(1).

Dewi, W. A. F. (2020). Dampak COVID-19 terhadap Implementasi Pembelajaran Daring di Sekolah Dasar. Edukatif: Jurnal Ilmu Pendidikan, 2(1), 55-61.

https://doi.org/10.31004/edukatif.v2i1.89

Dong, C., Cao, S., \& Li, H. (2020). Young children's online learning during COVID-19 pandemic: Chinese parents' beliefs and attitudes. Children and Youth Services Review, 118(June), 105440. https://doi.org/10.1016/j.childyouth.2020.105440

Hussein, E., Daoud, S., Alrabaiah, H., \& Badawi, R. (2020). Exploring undergraduate students' attitudes towards emergency online learning during COVID-19: A case from the UAE. Children and Youth Services Review, 119(November), 105699. https://doi.org/10.1016/j.childyouth.2020.105699

Nana Syaodih S. (2009). Pengembangan Kurikulum. Remaja Rosda Karya.

Pangondian, R. A., Santosa, P. I., \& Nugroho, E. (2019, F. (n.d.). .Faktor-Faktor Yang Mempengaruhi Kesuksesan Pembelajaran Daring Dalam Revolusi Industri 4.0. (Vol.1, N. Rahaju, R., \& Hartono, S. R. (2017). Pembelajaran Matematika Berbasis Permainan Monopoli Indonesia. JIPMat, 2(2). https://doi.org/10.26877/jipmat.v2i2.1977

Suciati, S., Septiana, I., \& Untari, M. F. A. (2015). Penerapan Media Monosa (Monopoli Bahasa) Berbasis Kemandirian Dalam Pembelajaran Di Sekolah Dasar. Mimbar Sekolah Dasar, 2(2), 175-188. https://doi.org/10.17509/mimbar-sd.v2i2.1328

Sugiyono. (2016). Metode penelitian kuantitatif, kualitatif dan R\&D. Alfabeta.

Triyana, P., Agustin, Y. D., Lailati, I., \& Yuniasih, N. (2019). Monopoli Elektronik (ME 3in1) Untuk Pembelajaran Di Sekolah Dasar Negeri Bandung Sejo Sari 3 Malang. Inventa, 3(2), 170-179. https://doi.org/10.36456/inventa.3.2.a2015 Ulfaeni, S. (2018). Pengembangan Media Monergi (Monopoli Energi) Untuk Menumbuhkan Kemampuan Pemahaman Konsep Ipa Siswa Kelas Iii Sdn Pedurungan Kidul 02 Semarang. Profesi Pendidikan Dasar, 1(2), 143. https://doi.org/10.23917/ppd.v1i2.4990. 